\title{
Updated Distribution of the Mysid Antromysis cenotensis (Crustacea: Peracarida), a Protected Key Species in Yucatan Peninsula Cenotes
}

\author{
Luis Arturo Liévano-Beltrán ${ }^{1,2}$ (D) and Nuno Simões $1,3,4, *$ (D) \\ 1 Unidad Multidisciplinaria de Docencia e Investigación, Facultad de Ciencias, Universidad Nacional \\ Autónoma de México, Puerto de Abrigo S/N, Sisal C.P. 97355, Yucatán, Mexico; lievano@ciencias.unam.mx \\ 2 Posgrado en Ciencias del Mar y Limnología, Universidad Nacional Autónoma de México, Avenida \\ Universidad 3000, Copilco-Universidad, Ciudad de Mexico 04510, Mexico \\ 3 Laboratorio Nacional de Resiliencia Costera (LANRESC), Puerto de Abrigo S/N, \\ Sisal C.P. 97355, Yucatán, Mexico \\ 4 International Chair for Ocean and Coastal Studies, Harte Research Institute, Texas A\&M at Corpus Christi, \\ Corpus Christi, TX 78412, USA \\ * Correspondence: ns@ciencias.unam.mx
}

Citation: Liévano-Beltrán, L.A.; Simões, N. Updated Distribution of the Mysid Antromysis cenotensis (Crustacea: Peracarida), a Protected Key Species in Yucatan Peninsula Cenotes. Diversity 2021, 13, 154 https://doi.org/10.3390/d13040154

Academic Editors: Michael Wink, Raoul Manenti and Enrico Lunghi

Received: 24 December 2020

Accepted: 24 March 2021

Published: 31 March 2021

Publisher's Note: MDPI stays neutra with regard to jurisdictional claims in published maps and institutional affiliations.

Copyright: (c) 2021 by the authors. Licensee MDPI, Basel, Switzerland. This article is an open access article distributed under the terms and conditions of the Creative Commons Attribution (CC BY) license (https:/ / creativecommons.org/licenses/by/ $4.0 /)$.

\begin{abstract}
We present 52 new geographic location records for the peracarid crustacean Antromysis cenotensis Creaser, 1936, endemic in cenotes of the Yucatan Peninsula, Mexico. This species is currently considered threatened and, therefore, is protected by Mexican law. These results arise from several expeditions carried out between 2017 and 2020 in 75 locations within the cenote-ring, the interior, and coastal plains of the peninsula. A comprehensive literature review provided 84 geographic location records since the species was described in 1936. A map with 136 geographic location records that better describe the current species distribution is also included. With this information, plus some notes on the ecology of the species, a comprehensive literature and data review, and a brief analysis regarding the possible factors associated with the confirmed absence of the species in some locations in the state of Yucatan, we provide a brief and condensed summary of the actual knowledge on this particular species. The data in Darwin Core format can be retrieved in Zenodo.
\end{abstract}

Keywords: environmental science; biogeography; distribution records; groundwater; cave biology; underwater caves; cenote; mysid; stygobiont; bioindicator

\section{Introduction}

The order Mysida (Crustacea: Malacostraca: Peracarida) contains 1184 species grouped into 179 genera that belong to two families and inhabits a vast diversity of aquatic habitats throughout the world [1]. Over $90 \%$ of the species are exclusively marine, while the remaining species inhabit subterranean freshwater and estuarine habitats. Mysids range in size from 3 to $22 \mathrm{~mm}$ and are often referred to as opossum shrimps due to the presence of oostegites forming a ventral female marsupium [2]. A statocyst in the proximal part of the endopods of the uropods characterizes the order and facilitates the distinction of these organisms from other crustaceans [3-5].

Mysids are considered omnivores, capable of both filter-feeding and raptorial feeding, exhibiting a variety of diets associated with seasonal changes, diel cycles, ontogenetic development, or food availability, and serve as an important food source for fish and crustaceans [6-9]. These organisms are usually positioned in the intermediate trophic levels of the communities they belong to, and some species play a key role in transferring energy between benthic and pelagic environments [9], and between upper and lower trophic levels [10]. They can be very abundant in certain habitats, reaching $>1000$ ind. $\mathrm{m}^{-2}[5,11]$, which added to the effect of vertical or horizontal migrations in most species, can have a significant impact on food-web dynamics, capable of attenuating the selective 
pressure generated by oligotrophy in some scenarios $[6,8,12]$. In addition to their ecological importance, mysids are also used as bioindicators or models for environmental screening in aquatic ecosystems, owing to their sensitivity to changes in water quality and the toxicity of chemical agents such as repellents, pesticides, and fertilizers [13-15].

Stygobionts are highly specialized aquatic organisms that inhabit hypogeal ecosystems [16]. In Mexico stygobiont mysids include representatives within the Antromysis and Spelaeomysis genera: A. cenotensis Creaser 1936 and A. reddelli Bowman, 1977, endemic to the Yucatan Peninsula and Oaxaca respectively, and $S$. quinterensis Villalobos, 1951 and S. villalobosi García-Garza, Rodríguez-Almaraz \& Bowman, 1996, from Tamaulipas and Monterrey. A. cenotensis.

Figure 1 was discovered during the first investigations carried out in 1932 by the Carnegie Institution of Washington, focused on the systematic study of stygobitic fauna inhabiting caves and sinkholes, locally called cenotes, found throughout the karstic terrain of the Yucatan Peninsula which connect subterranean passages that can range from several meters to $>350 \mathrm{~km}$ long [17]. Creaser [18] formally described the species, and Reddell [19] elaborated an extensive compilation of records by several authors which allowed for the first formal study of the species distribution. Said distribution delimited the species reach to freshwater cenotes found on the coastal plain north of the Sierra de Ticul and the TulumCoba corridor. Thanks to the development of specialized cave diving techniques in the mid1980s, more profound explorations and complex studies on groundwater ecosystems with different approaches have been possible [20]. One particular study by Pohlman, et al. [21] shed light on the species ecology through stable isotope analysis, which established $A$. cenotensis as a primary consumer at the middle levels of the trophic chain. Therefore, the species appears to be an important component of groundwater biological communities, given its abundance and position in the food-web [20,21].

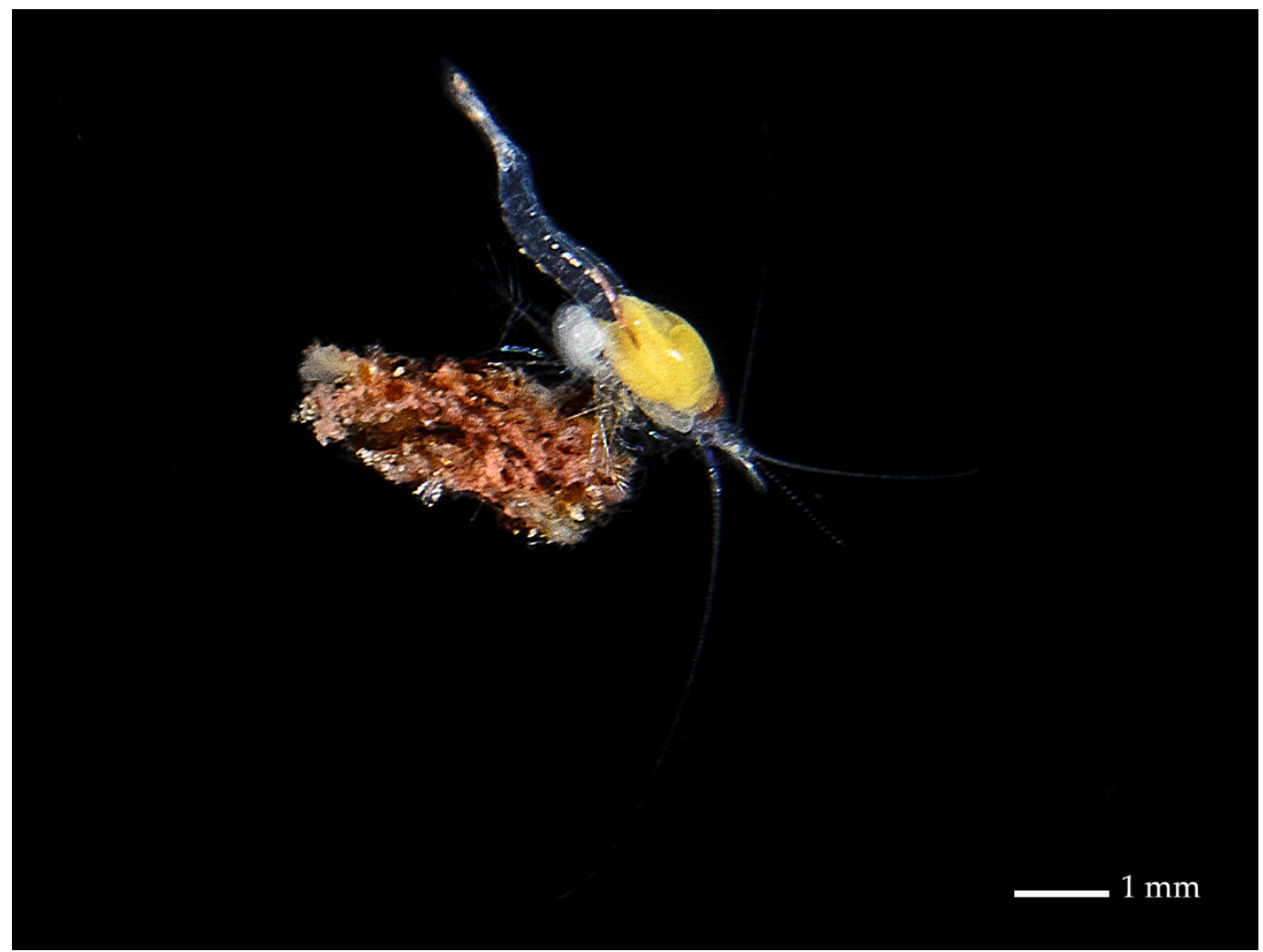

Figure 1. A. cenotensis holding a piece of organic detritus, typically observed during raptorial feeding. Cenote Kanún, Homún at $17 \mathrm{~m}$ in depth in September 2017. Photography courtesy of Benjamín Magaña-Rodríguez. 
According to the National Water Commission (Comisión Nacional del Agua, CONAGUA [22]), groundwater in the Yucatan Peninsula is divided into four aquifers which comprise the states of Yucatan, Campeche, and Quintana Roo [22]. They are underlain by saltwater originated from marine intrusion [23]. The interaction of groundwater with primary and secondary geological features within the peninsula allowed for the formation of five main hydrogeological zones: the coastal plain, the cenote semicircle, the interior plain, hills and valleys and stepped basins [22]. They are highly vulnerable to pollution due to their karstic, hydraulic, and ground properties, while the northern portion is highly susceptible to impact by human activities due to the velocity at which external agents can enter [22].

The coastal plain includes barrier beaches, flood lagoons and a series of shallow bays associated with fracture systems and highly permeable semi-consolidated coastal environment coquiniferous limestone systems. Its delimitation is based on an imaginary $20 \mathrm{~km}$ fringe running parallel to the coastline from Campeche to Quintana Roo and is characterized by a thin freshwater layer underlain by marine water [22-24]. The cenote semicircle is delimited by a fracture system related to the Chicxulub Crater, forming an almost perfect semicircular cenote boundary surrounding a fracture system of approximately $170 \mathrm{~km}$ in diameter. It has lateral groundwater migration and large flow due to dissolution and subsidence along the fractures at the edges and receives a small vertical recharge [22-24]. The interior plain extends towards the northern and northeast portions of the peninsula. It is underlain by permeable limestone and contains karst forms that range from dissolution cavities to sinkholes with mature and juvenile development. It borders to the north with the semicircle of cenotes and the coastal region, and to the south with the zones of hills and valleys and stepped basins [22,24]. The hills and valleys zone represents the most complex zone due to the Puuc Cordon, its elevation and topographical relief. It is formed by highly permeable carbonates and is characterized by a fault line that divides it from the interior plain. In contrast with the other zones, cenotes are almost inexistent, although there are dry caves of great dimensions [22,24]. Finally, the stepped basins extend from the northeast portion of the peninsula near cape Catoche in Quintana Roo towards the southern border with Belize. This area contains the largest fracture concentration. The interaction of gypsum, loam, anhydrite, and limestone make it highly permeable, with poor water quality [22].

In the state of Yucatan, groundwater exhibits variations in water quality in a stratified manner, where the topmost layer is polluted through poorly designed wells used for clandestine residual discharges that reach a depth of $20 \mathrm{~m}$ [24]. Freshwater depth varies according to its distance from the coast, ranging from 1-5 $\mathrm{m}$ in depth in the coastal plain, $10-30 \mathrm{~m}$ in the cenote semi-circle, and $60-100 \mathrm{~m}$ further south. Below these depths, saltwater intrusion occurs $[23,24]$. The interior plain covers most of the state $(52 \%$ of the surface), followed by the cenote semicircle (18\%), the coastal plain (17\%) and the hills and valleys zone (13\%) [24].

At present, A. cenotensis is a threatened species listed in the Mexican Red List of Species at Risk from the Secretariat of the Environment and Natural Resources (NOM-059 SEMARNAT 2010, Secretaría de Medio Ambiente y Recursos Naturales). This category includes species in danger of disappearing in the short or medium-term by factors causing habitat deterioration or directly affecting their population sizes. It partially coincides with the vulnerable category of the IUCN Red List, which A. cenotensis is not part of.

Given the current urbanization and degradation processes within the Yucatan Peninsula and their associated environmental impacts on groundwater habitats [25], the monitoring of this species, and ecological information related to it, will gain importance. Thus, we present an update on the distribution of the species in several locations within the Yucatan Peninsula, and a historical summary of distribution records available for the species. 


\section{Materials and Methods}

\subsection{Bibliographic Review}

To obtain the current knowledge about the distribution of $A$. cenotensis, a comprehensive bibliographic review was carried out following the Preferred Reporting Items for Systematic Reviews and Meta-Analyses (PRISMA) statement guidelines [26] on 5 February 2021. Publications and records were obtained through a comprehensive search for information in biological collections, which included the Smithsonian Invertebrate Zoology Collection (NMNH [27]) and the National Crustacean Collection from the Biology Institute, National Autonomous University of Mexico (Colección Nacional de Crustáceos del Instituto de Biología de la Universidad Nacional Autónoma de México, CNCR [28]), literary databases $[29,30]$, scientific search engines [31-33], and online biodiversity and citizen science databases [34-36]. Inclusion criteria were (1) publications or data sets that had to explicitly mention the collection or presence of specimens in a specific location and (2) biological records that had to comprise discrete events validated through specimens stored in scientific collections with relevant geographic information. More information is available in PRISMA statements (Figures S1 and S2).

\subsection{Specimen Collection}

Between November 2017 and November 2020, 75 dives were carried out in cenotes from the Yucatan Peninsula lacking biological information related to A. cenotensis. Fifteen of these locations are found within the coastal zone of the state of Quintana Roo, while the remaining 60 are distributed within the hydrogeological units of the coastal plain, the cenote semicircle and the interior plain in the state of Yucatan as shown in Figure 2.

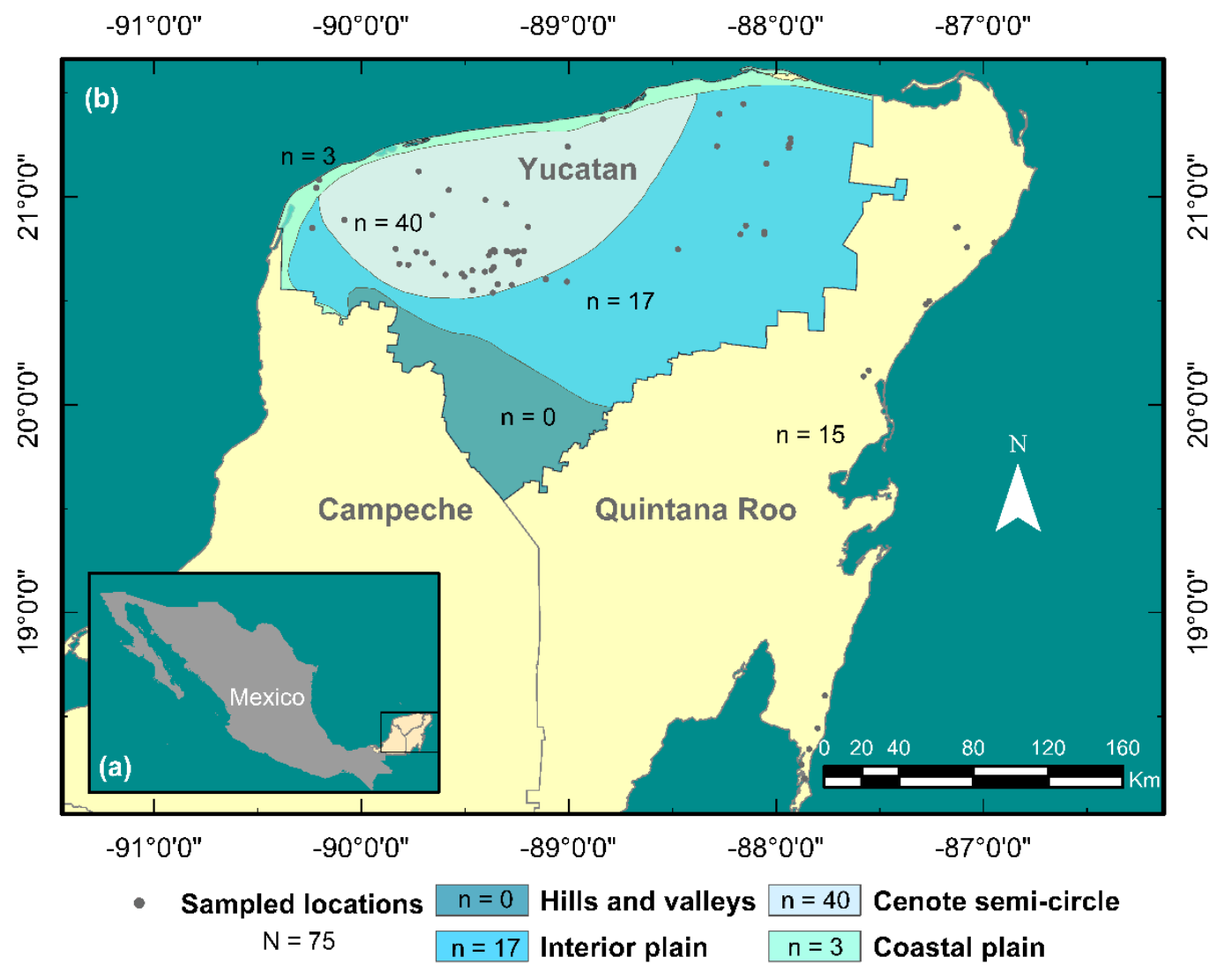

Figure 2. (a) Map of Mexico with Yucatan Peninsula highlighted in yellow. (b) Sampled locations (dots) along the coastal region of Quintana Roo, and the hydrogeological zones within the state of Yucatan [24]. Total number of locations sampled $(\mathrm{N})$ is shown in the legend. Number of sampled locations per geohydrological zone (n) are shown on the map close to each region and the legend as well. 
The collection of organisms was carried out manually by an average of two cave-divers or free-divers using aquarium nets and $50 \mathrm{~mL}$ plastic tubes in the pool (photic region), cavern (twilight region) and cave (aphotic region) of each location (Figure 3). Specimen collections were made in 52 locations at a maximum depth of $36 \mathrm{~m}$, with a maximum penetration of $900 \mathrm{~m}$ by cave divers, and seven locations at a maximum depth of $9 \mathrm{~m}$ by free-divers. The specimens were immediately preserved and stored in $70 \%$ ethanol after each dive and were collected under permits: SEMARNAT/SPGA/DGVS/05263/14; and SEMARNAT/SPGA/DGVS/02068/17 issued by the Ministry of the Environment and Natural Resources (Secretaría de Medio Ambiente y Recursos Naturales, SEMARNAT).

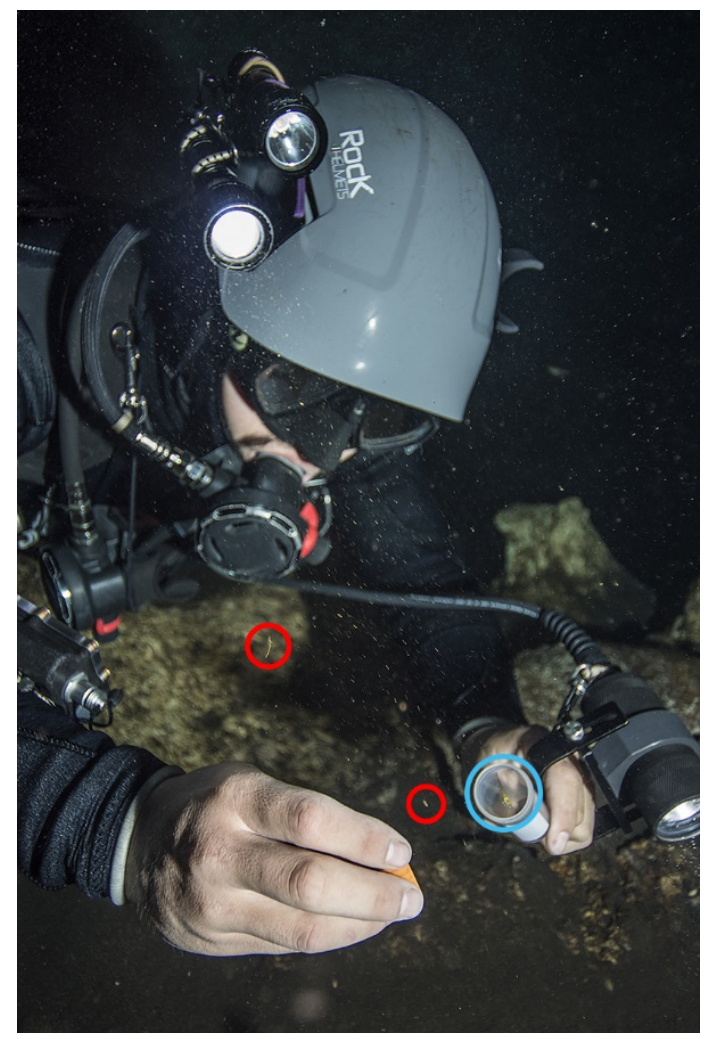

Figure 3. Luis Arturo Liévano-Beltrán collecting A. cenotensis (red circles) and T. mitchelli (blue circle) specimens from a cave in cenote Xelactún at $24 \mathrm{~m}$ depth on 25 February 2020. Courtesy of Kayú Vilchis-Zapata.

All organisms were identified at the species level according to Bowman [37], using stereoscopic and optical microscopes. Identified specimens were stored in the Colección de Crustáceos de Yucatán, Unidad Multidisciplinaria de Docencia e Investigación, Universidad Nacional Autónoma de México (UMDI-Sisal, UNAM) under catalog codes YUC-CC255-11-006806-YUC-CC-255-11-006857. The obtained data comprised dates, GPS coordinates, geographical information, cenote type, depth, number of specimens collected and collection codes. Data were transformed into the Darwin Core format and made available for public access through Zenodo (https: / / doi.org/10.5281/zenodo.4391039, accessed on 26 February 2021) following the Global Biodiversity Information Facility (GBIF) current best practices for generalizing sensitive species occurrence data [38].

\subsection{Map Ellaboration}

Geospatial data/information/coordinates were extracted from obtained publications during the bibliography review. Maps were designed using QGIS v. 3.16 (QGIS Development Team, 2020). Topographic, hydrogeological, agricultural and livestock maps at 
1:1,000,000 were used to illustrate and relate socioeconomic aspects with the current distribution of A. cenotensis in the Yucatan Peninsula (CONABIO [39]; POETY [40]).

\section{Results}

\subsection{An Account of A. cenotensis Historical Distribution Records}

A total of 86 publications mentioning $A$. cenotensis were reviewed (Figure S1). Thirty publications contained valuable data for the current study, 14 lacked information on the species and 39 were secondary references to previously published material/data/information missing extractable geospatial information. Furthermore, 121 records were extracted from these publications and 52 were gathered through database and collection searching (Figure S2), adding 173 records. However, 15 were accounted for in literature, and 32 did not contain extractable location information, leaving 126 validated historical records for $A$. cenotensis corresponding to 84 locations.

The fastest rate of record contributions for the species occurred from its description until the end of the seventies, with a more gradual increase until the year 2020 (Figure 4a), with a contribution of 20 records by Angyal et al. [41]. Ninety-eight records correspond to 65 locations within the state of Yucatan. The remaining 28 refer to 19 locations in Quintana Roo (Figure 4b). The main location record contributor was Bowman [37] as shown in Figure 4c. Record contributions per author for each year can be found in Table 1, and a map displaying recorded locations with their record count is shown in Figure 5.
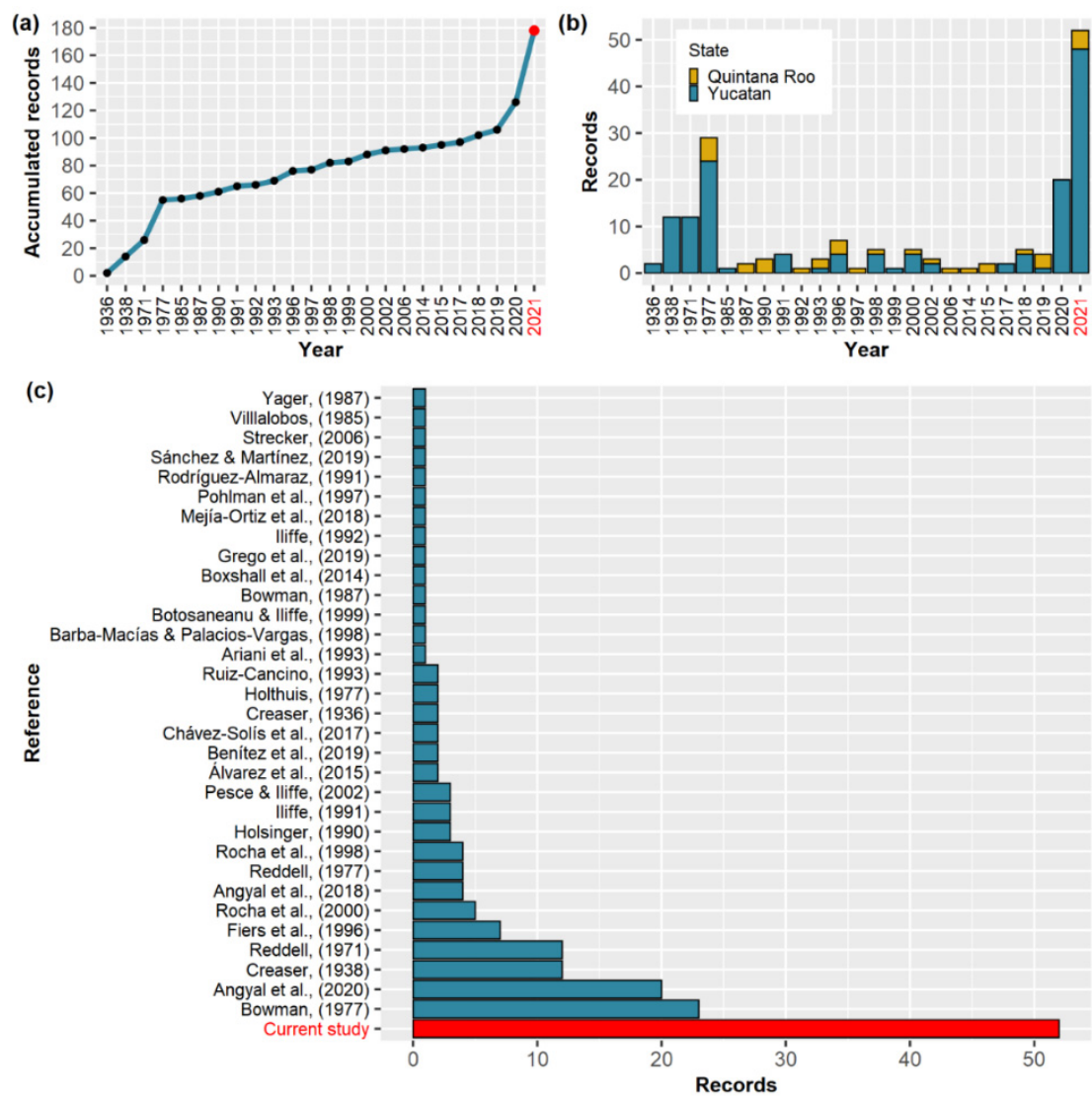

Figure 4. (a) Number of accumulated A. cenotensis records per year since species description filtered from duplicates and cross-referencing (see PRISMA statements from Figures S1 and S2). (b) Number of A. cenotensis records per year in the Yucatan Peninsula. (c) Author record contribution ordered according to contribution frequency. Red color indicates present study results. Main record contributors $[37,41]$ are found in the Reference column from Table 1 along with others. Locations for each record are summarized in Table 1. A map with the recorded locations can be visualized in Figure 5. 
Table 1. Locations where A. cenotensis records have been published per year for the states of Quintana Roo and Yucatan. Location geographical distribution and names can be found in Figure 5.

\begin{tabular}{|c|c|c|c|c|c|}
\hline State & Year & Author & $\mathbf{N}$ & Locations & Reference \\
\hline \multirow[t]{17}{*}{ Q. Roo } & 1977 & Bowman & 5 & $69,70,73,77,81$ & [37] \\
\hline & \multirow[t]{2}{*}{1987} & Bowman & 1 & 79 & [42] \\
\hline & & Yager & 1 & 77 & [43] \\
\hline & 1990 & Holsinger & 3 & $74,77,79$ & [44] \\
\hline & 1992 & Iliffe & 1 & 79 & [20] \\
\hline & 1993 & Ruiz-Cancino & 2 & 83,84 & [45] \\
\hline & 1996 & Fiers et al. & 3 & $66,68,71$ & [46] \\
\hline & 1997 & Pohlman et al. & 1 & 75 & [21] \\
\hline & 1998 & Rocha et al. & 1 & 75 & [47] \\
\hline & 2000 & Rocha et al. & 1 & 72 & [48] \\
\hline & 2002 & Pesce \& Iliffe & 1 & 75 & [49] \\
\hline & 2006 & Strecker & 1 & 67 & [50] \\
\hline & 2014 & Boxshall et al. & 1 & 77 & [51] \\
\hline & 2015 & Álvarez et al. & 2 & 76,78 & [52] \\
\hline & 2018 & Mejía-Ortiz et al. & 1 & 82 & [53] \\
\hline & \multirow[t]{2}{*}{2019} & Benítez et al. & 2 & 76,78 & [54] \\
\hline & & $\begin{array}{l}\text { Sánchez \& } \\
\text { Martínez }\end{array}$ & 1 & 80 & [55] \\
\hline \multirow[t]{20}{*}{ Yucatan } & 1936 & Creaser & 2 & 17,54 & [18] \\
\hline & 1938 & Creaser & 12 & $\begin{array}{r}4,12,17,31,39,46 \\
50,53,54,55,56,60\end{array}$ & [56] \\
\hline & 1971 & Reddell & 11 & $\begin{array}{r}4,12,17,31,39,46 \\
50,53,54,55,56,60\end{array}$ & [57] \\
\hline & \multirow[t]{3}{*}{1977} & Bowman & 18 & $\begin{array}{c}3,5,13,14,17,19,20 \\
25,27,29,36,42,46 \\
61,62,63,64,65\end{array}$ & [37] \\
\hline & & Holthuis & 2 & 57,59 & [58] \\
\hline & & Reddell & 4 & $6,9,15,30$ & [19] \\
\hline & 1985 & Villalobos & 1 & 57 & [28] \\
\hline & \multirow[t]{2}{*}{1991} & Iliffe & 3 & $38,55,57$ & [27] \\
\hline & & $\begin{array}{l}\text { Rodríguez- } \\
\text { Almaraz }\end{array}$ & 1 & 49 & [27] \\
\hline & 1993 & Ariani et al. & 1 & 27 & [59] \\
\hline & 1996 & Fiers et al. & 4 & $2,21,23,58$ & [46] \\
\hline & \multirow[t]{2}{*}{1998} & $\begin{array}{l}\text { Barba-Macías \& } \\
\text { Palacios-Vargas }\end{array}$ & 1 & 27 & {$[60]$} \\
\hline & & Rocha et al. & 3 & $21,27,37$ & [47] \\
\hline & 1999 & $\begin{array}{l}\text { Botosaneanu \& } \\
\text { Iliffe }\end{array}$ & 1 & 24 & {$[61]$} \\
\hline & 2000 & Rocha et al. & 4 & $21,27,37,41$ & [48] \\
\hline & 2002 & Pesce \& Iliffe & 2 & 23,52 & [49] \\
\hline & 2017 & Chávez-Solís et al. & 2 & 18,38 & [62] \\
\hline & 2018 & Angyal et al. & 4 & $10,18,43,44$ & [63] \\
\hline & 2019 & Grego et al. & 1 & 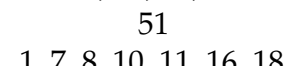 & [64] \\
\hline & 2020 & Angyal et al. & 20 & $\begin{array}{c}1,7,8,10,11,16,18 \\
22,26,28,32,33,34 \\
35,40,43,44,45,47 \\
48\end{array}$ & [41] \\
\hline
\end{tabular}




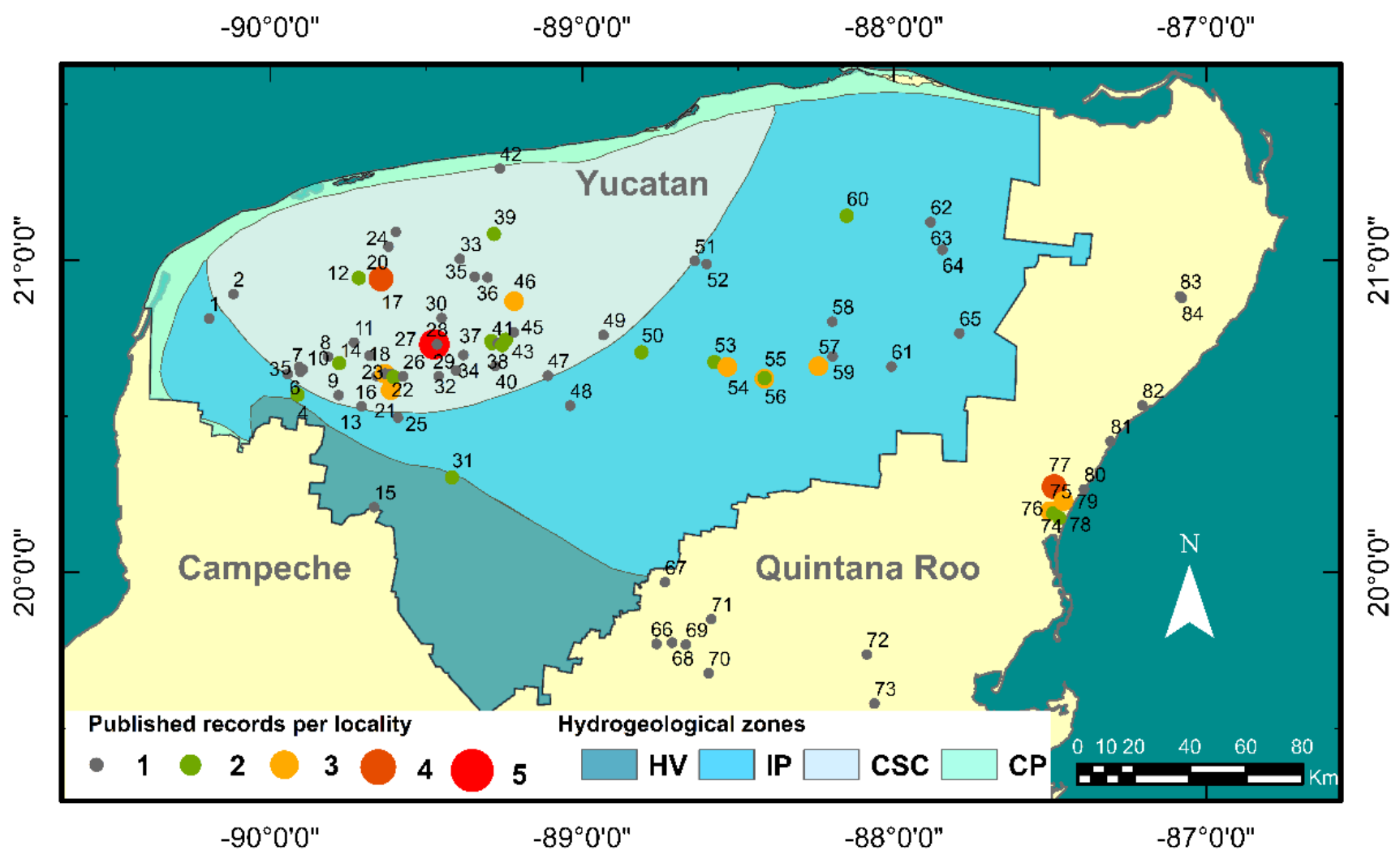

Figure 5. Known locations (dots) where at least one individual of A. cenotensis was previously reported in literature and/or scientific collections. Number of records/occurrences over time per location (dot color and size). Hills and valleys (HV), interior plain (IP), cenote semi-circle (CSC), and coastal plain (CP) hydrogeological zones in the state of Yucatan. Location name is presented along with the municipality where it is found (between parentheses) for each state (italics). Yucatán: (1) Noh Chucunchey (Celestún); (2) well (Kinchil); (3) Calchum (Kopomá); (4) well (Calcehtok); (5) Cenote de las Abejas (Kopomá); (6) San Bulhá (Kopomá); (7) San Tito (Kopomá); (8) Pool Box (Chocholá); (9) Cenote del Pochote (Opichén); (10) Dzonbakal (Chocholá); (11) Bebelchén (Sanahcat); (12) Luchil (Mérida); (13) Cenote de la Culebra (Muna); (14) Sihunchén (Abalá); (15) Aktún Chac (Sayil); (16) Dzonotilá (Abalá); (17) Cueva de San Isidro (Mérida); (18) Kankirixché (Abalá); (19) Kankirixché (Muna); (20) Sodzil (Mérida); (21) Yuncú (Mucuyché); (22) Chihuo-hol (Abalá); (23) Mucuyché (Mucuyché); (24) X'lakah (Mérida); (25) Noh Chén (Sacalum); (26) X'kakuel (Abalá); (27) Grutas de Tzab Nah (Tecoh); (28) Tza Itzá (Tecoh); (29) Chen Mul (Tecoh); (30) Chun Kapoc (Acanceh); (31) Well (Oxkutzcab); (32) Nah Yah (Tecoh); (33) Flor de Liz (Tixkokob); (34) Kampepén (Tecoh); (35) X’kokob (Tixkokob); (36) Cenote G (Tixkokob); (37) Grutas de Santa María (Homún); (38) San Juan (Homún); (39) Sambulá (Motul); (40) Kankal (Homún); (41) Chan-hoch (Homún); (42) Pozo de Santa Elena (Sinanché); (43) Xa'an (Homún); (44) Kanún (Homún); (45) Pixtón (Sanahcat); (46) Hoctún (Hoctún); (47) Ixim Ha (Huhí); (48) El Virgen (Sotuta); (49) Chihuán (Kantunil); (50) Yuhunchén (Libre Unión); (51) Xoch (Cenotillo); (52) Ucil (Cenotillo); (53) Chaac Mol (Tinum); (54) Balamcanché (Tinum); (55) Aktún Kaua (Kaua); (56) Oxolodt (Kaua); (57) X’kekén (Dzitnup); (58) well (Temozón); (59) Zací (Valladolid); (60) X’consacab (Tizimín); (61) Xtacabihá (also known as Xalaú, Chemax); (62) Cueva de Orizaba (Tizimín); (63) Cenote Orizaba (Tizimín); (64) Aka Chén (Tizimín); (65) San Diego (Chemax). Quintana Roo: (66) well 1 (Jose María Morelos); (67) water spring (José María Morelos); (68) well 2 (Jose María Morelos); (69) Santo Domingo (José María Morelos); (70) Cenote de Las Ruinas (José María Morelos); (71) Aguada (José María Morelos); (72) Tos Virlol (Felipe Carrillo Puerto); (73) Cenote de Juan Coh (Felipe Carrillo Puerto); (74) Naharón (Tulum); (75) Mayan Blue (Tulum); (76) Muknal (also known as Jailhouse, Tulum); (77) Aktún Ha (also known as Carwash, Tulum); (78) Odissey (Tulum); (79) Calavera (also known as Temple of Doom, Tulum); (80) Cenote Manatí (also known as Casa Cenote, Tulum); (81) San Martín (Solidaridad); (82) Muévelo Rico (Solidaridad); (83) Aktún Jaleb (Benito Juárez); (84) Tres Bocas (Benito Juárez). 


\subsection{New Records}

We present 52 new A. cenotensis distribution records from cenotes in the Yucatan Peninsula (Figure 6), four in the Quintana Roo state and 48 in Yucatan. The provided records account for a $41 \%$ increase in existing records and a $62 \%$ increase in locations since the species description. Nineteen locations were previously reported in the state of Quintana Roo, and 65 in Yucatan. So far A. cenotensis has not been reported in the state of Campeche. The number of records obtained during this study added to those obtained through the bibliographic review adds up to a total of 178 records corresponding to 136 locations. Twenty-three in the state of Quintana Roo and 113 in Yucatán.

A. cenotensis individuals were collected mainly from cenotes that either had clear waters with no apparent smell or taste (cenotes from the cenote semicircle), a freshwater region in the cave zone above the halocline (Tajma Ha) or were at least $2 \mathrm{~km}$ away from the coast. However, in some locations with these characteristics the species could not be found (Figure 7). These locations include mostly cenotes from the interior plain where high touristic (Hubikú), agricultural (Saa'kal, X'bohom, cenote under papaya plantation), or livestock activities (Tzitzilá, Rancho Sac Bé) took place.

Some locations where the species was not found were cenotes with yellow or green turbid water (Crustacea, K'ax Ek), saltwater regions below the halocline in coastal cenotes (Sabtún, Dagobah, Cocom) and locations with wine-colored water in mangroves (Polac, Cauich) or the jungle. On occasions, thick white or brownish clouds with a rotten egg taste were present (Angelita, Tzitzilá, Sabtún), and slimy bacterial mats covering the walls precipitated towards the bottom when disturbed by diver bubbles (Pandora, Dagobah).

Specimens were collected in all the sampled locations within the cenote semicircle (present $=40$, absent $=0$ ) but their presence decreased towards the interior plain (present $=8$, absent $=10$ ), and were mostly absent in coastal regions (present $=4$, absent $=13$ ).

During this study, A. cenotensis was observed coexisting with a variety of animals that included predatory fish species like Ophisternon infernale (Hubbs, 1938), Rhamdia guatemalensis (Günther, 1864), and Typhlias pearsei (Hubbs, 1938), known to feed on smaller crustaceans [21,65-69]. Decapods like Creaseria morleyi (Creaser, 1936), (predator of A. cenotensis) [62], Typhlatya dzilamensis, Alvarez, Iliffe \& Villalobos, 2005, Typhlatya mitchelli, Hobbs \& Hobbs, 1976, and Typhlatya pearsei, Creaser, 1936. The isopods Cirolana yunca, (Botosaneanu \& Iliffe, 1999), Creaseriella anops, (Creaser, 1936), Metacirolana mayana (Bowman, 1987), and Yucatalana robustispina, Botosaneanu \& Iliffe, 1999. The amphipods Mayaweckelia troglomorpha, Angyal, 2018, Mayaweckelia cenoticola, Holsinger, 1977, and Tuluweckelia cernua, Holsinger, 1990. The thermosbaenacean Tulumella unidens, Bowman \& Iliffe, 1988, and the stygiomysids Stygiomysis cokei, Kallmeyer \& Carpenther, 1996 and Stygiomysis holthuisi, (Gordon, 1958). The number of coexisting species varied between locations. However, none of these species displayed populations as large as those for A. cenotensis, on occasions containing thousands of individuals. This makes this species an exceptionally important component within the community. 


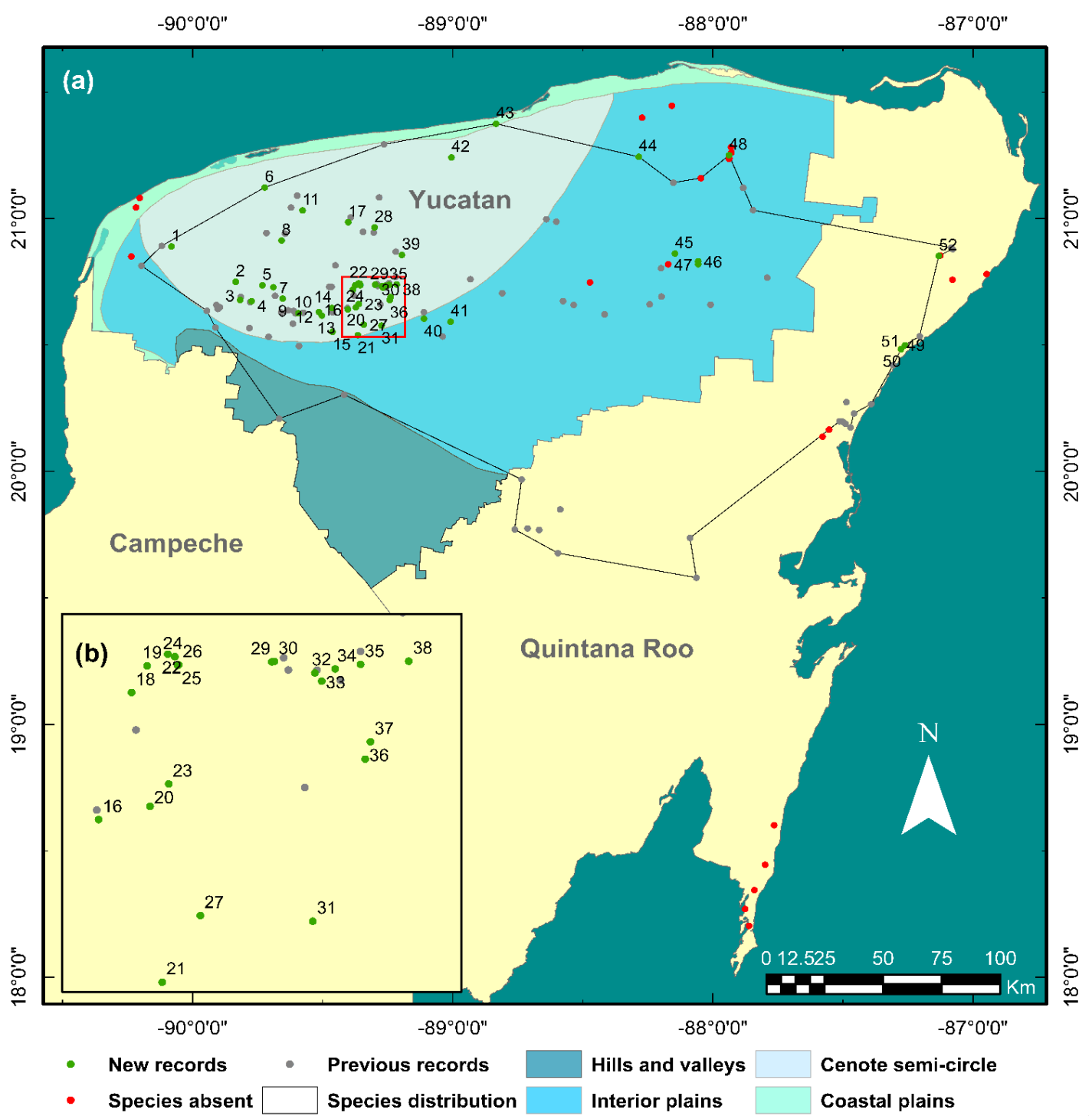

Figure 6. (a) New records for A. cenotensis (green dots), locations where the species was not found (red dots, named in Figure 7), previous records (gray dots), and current species distribution (polygon) extracted from total available data. (b) Close-up of stacked new records (in red square). Hydrogeological zones are also shown for the state of Yucatan. Location names are presented along with the municipality where it is found (between parentheses) for each state (italics). Yucatán: (1) Xelactún (Celestún); (2) San Ignacio (Chocholá); (3) X’baba (Chocholá); (4) X’batún (Chocholá); (5) Eku'he (Umán); (6) Sierra Papacal (Mérida); (7) Pebá (Abalá); (8) Huul K’in (Mérida); (9) Temozón (Abalá); (10) Yax Kis (Abalá); (11) Xoc (Mérida); (12) Itzkakal (Tecoh); (13) Itzinteh (Tecoh); (14) Cheen Cha'ac (Telchaquillo); (15) Mazucil (Tecoh); (16) Suem (Tecoh); (17) Yaax Ha (Tixkokob); (18) Boloonchojol (Cuzamá); (19) Paraíso Papacal (Cuzamá); (20) Tanimax (Tecoh); (21) X'pakay (Tekit); (22) X'tojil (Cuzamá); (23) Calcuch (Tecoh); (24) San Felipe (Cuzamá); (25) Saak Pakal (Cuzamá); (26) Ayusó (Cuzamá); (27) Uitzán (Tekit); (28) X'cohil (Cacalchén); (29) Pool Uinic (Homún); (30) Tza Ujun Kat (Homún); (31) Becal (Tekit); (32) Tres Oches (Homún); (33) Yaxbacaltún (Homún); (34) Los Huayes (Homún); (35) Chulul (Homún); (36) Oxolá (Homún); (37) San Elías (Homún); (38) Subinteh (Homún); (39) Ehbiz (Hoctún); (40) X'toho (Sotuta); (41) Tzonot Mis (Sotuta); (42) Sacahuá (Dzidzantún); (43) Cervera (Dzilam de Bravo); (44) Acancún (Panabá); (45) Santa Rita (Temozón); (46) Dzalbay (Tizimín); (47) Palomitas (Temozón); (48) Yaxcabá (Tizimín). Quintana Roo: (49) Tajma Ha (Tulum); (50) Buenavista (Tulum); (51) X'tabay (Tulum); (52) Hol Box (Benito Juárez).

\section{Discussion}

A. cenotensis is highly conspicuous in many cenotes of the Yucatan Peninsula, particularly those within the cenote semicircle. Its presence decreases towards the coastal regions and the southern edge of the Yucatan state (Figure 7). These data may be biased associated 
with sampling effort, considering most records come from the cenote semicircle in the Yucatan state. However, the absence/presence relationships in this study increased from the cenote semicircle towards the interior plain of the Yucatan state, with a high number of absences in the coastal regions of Yucatan and Quintana Roo.

The observed decrease in presence towards the coast may be related to environmental factors known to influence community structure, such as an uplift in the halocline due to tidal fluctuations [70]. This would convert the halocline into a mobile physicochemical barrier for the species capable of restricting its habitat. Consequently, the species would be forced to modify its feeding strategies by not being able to access bottom nutrients [71,72]. Major geological changes in the karst landscape may explain the presence decrease towards the southern edge of the state [23], where the Sierrita de Ticul fracture zone acts as an allopatric barrier to the distribution of the species.

The species usually exhibited conspicuously large population sizes, coexisting with a variety of stygobiont representatives. Groundwater ecosystems are known to be regulated through bottom-up trophic cascades $[21,25,73,74]$. In such habitats, $A$. cenotensis may act as an energy facilitator capable of feeding-off a combination of sources, such as soil particulate organic matter that percolates through the porous bedrock into the cave, and algal and vegetative detritus found near the cenote pool [21]. The species also serves as a readily available food source for other predatory stygobiont species [21,62,65-69]. Therefore, $A$. cenotensis may play an important role in the food-web dynamics as a mid-level prey in groundwater communities.

Over 3000 cenotes and caves have been registered within the state of Yucatan by the Secretariat of Sustainable Development of the Government of Yucatan (Secretaría de Desarrollo Sustentable del Gobierno del Estado de Yucatán, SDS). However, Steinich [75] estimated a figure of 7000 cenotes throughout the northwestern part of the Yucatan Peninsula through topographic digitalization. This would extend the current knowledge of A. cenotensis to approximately $4.5 \%$ of its potential habitat for the Yucatán state cenotes and $1.92 \%$ of the estimated total for the Yucatan Peninsula, without including caves or wells. Many locations remain undiscovered or lack biological information and A. cenotensis

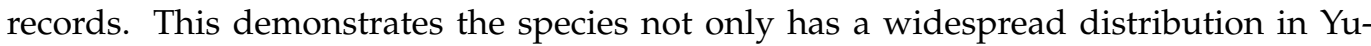
catan Peninsula but may also have a higher presence than current knowledge suggests. Therefore, further exploration and sampling efforts are required to describe the species distribution accurately.

Most of the locations where the species was collected can be classified as lotic cenotes according to Schmitter-Soto, et al. [25]. These contain clear, well-oxygenated water columns with sandy or rocky bottoms due to their connection with groundwater. On the contrary, we did not find the species in 24 of the studied locations, corresponding to $32.4 \%$ of the sampled total (Figures 6 and 7). Some of these locations had previous records for the species. Thus, our findings do not necessarily ensure the species' absence, but may imply less abundant populations that may require a higher sampling effort, or other phenomena which could influence the species distribution on a small scale.

The absence of the species in saltwater portions of locations found within the coastal plain may not be a matter of major environmental concern, given that salinity conditions may exceed the physiological requirements that allow for the species survival. Furthermore, saltwater stygofauna representatives such as Metacirolana mayana, Tulumella unidens, Typhlatya dzilamensis and Xibalbanus tulumensis, were observed in the water column at several of these locations. In contrast, the absence of the species and other stygobionts was clear in mangrove or lentic cenotes [25] with a high input of tannic acid [76] and thick white $\mathrm{H}_{2} \mathrm{~S}$ smelling clouds, characteristic of anoxic waters where bacterial sulfate reduction and organic matter decomposition take place [25,76-80]. This serves as evidence that $A$. cenotensis populations may present naturally selected physiological limitations that make them sensitive to modifications in water quality and environmental conditions under certain scenarios. 
It is not clear why stygofauna was absent in some inland cenotes lacking coastal cenote characteristics within the interior plain [25]. This suggests that other non-natural factors may influence its presence. Furthermore, tourism, agriculture, and livestock activities can induce considerable impacts on karstic landscapes and groundwater biodiversity [81-88].

The municipality of Tizimin (Figure 7) is known for its agricultural and livestock activities [89-92]. Both promote land-use modification, pesticide or fertilizer use, groundwater extraction and vegetation removal. These favor soil compaction, nitrate and metabolically persistent chemical input, water table decrease, sedimentation rate and leaching or runoff of surface materials $[71,86,93,94]$. Climatological phenomena (e.g., precipitation, climate change, storms) can also alter abiotic conditions through surface pollutant transport, inducing potentially rapid responses in biological communities and processes [94-100]. Three records for the species came from this area from over 40 years ago $[18,37,56]$. Thus, the observed absence of stygofauna could be potentially linked to environmental pressures exerted by these activities. However, further research on the effect of water contaminants on stygobiont species from this region is required.

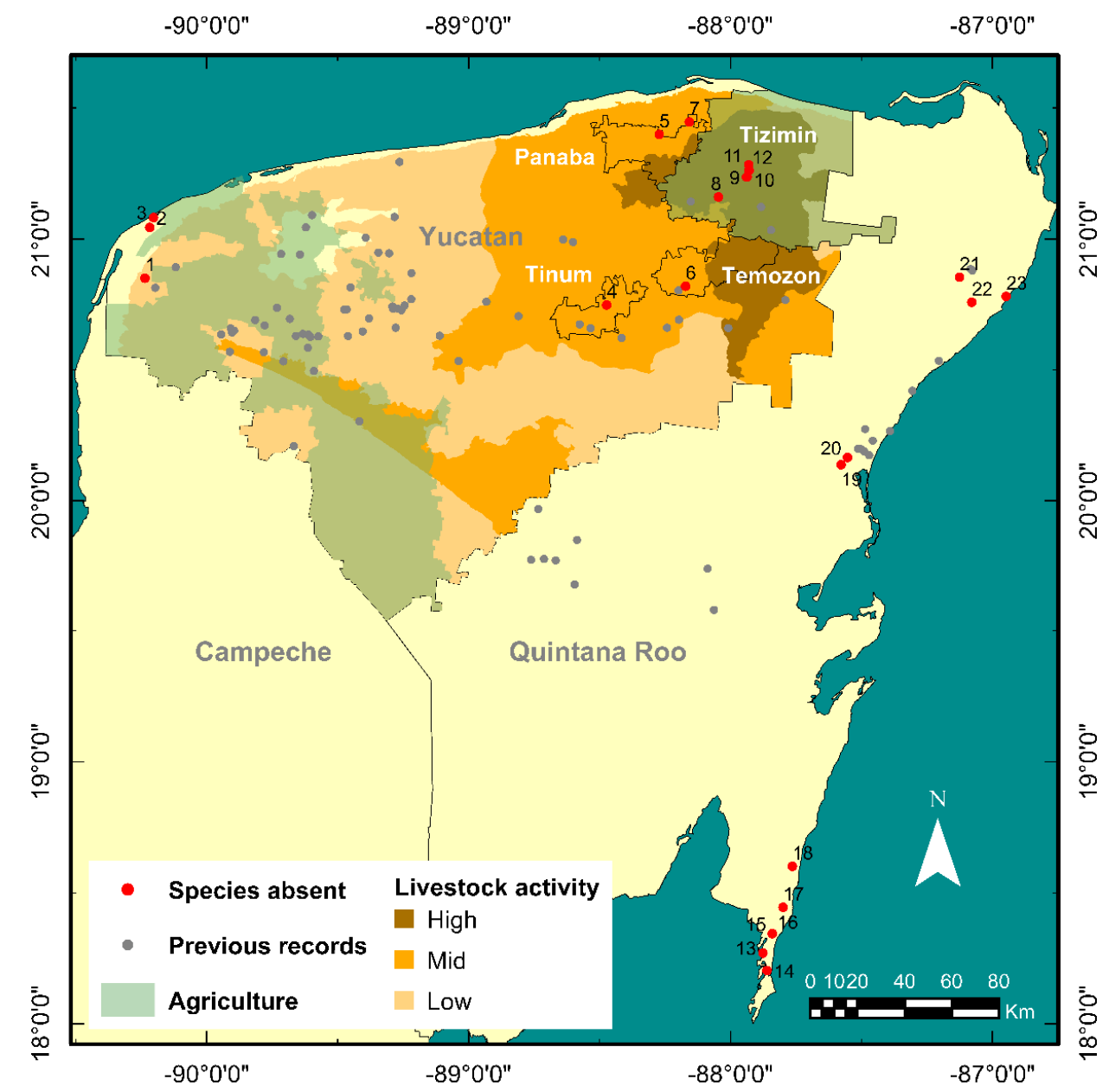

Figure 7. Regions with agricultural activity (green zones) and livestock activity intensity (brown zones) within the state of Yucatán $[40,89,90]$. Four municipalities in the state of Yucatan (outlined in black with white labels). Locations where A. cenotensis was not sighted (red dots) are numbered as follows according to state (bold italics) and municipality (in parenthesis): Yucatan: (1) Sabtún (Celestún); (2) Cauich (El Palmar); (3) Polac (El Palmar); (4) K'ax Ek (Tinum); (5) Rancho Sacbé (Panabá); (6) Hubikú (Temozón); (7) San Juan del Río (Panabá); (8) Saa'kal (Tizimín); (9) X’bohom (Tizimín); (10) Dzonot Aké (Tizimín); (11) unnamed cenote under papaya plantation (Tizimín); (12) Tzitzilá (Tizimín). Quintana Roo: (13) Pandora (Othón P. Blanco); (14) Bajo de Judas (Othón P. Blanco); (15) water spring (Othón P. Blanco); (16) water spring (Othón P. Blanco); (17) mangrove cenote (Othón P. Blanco); (18) Dagobah (Othón P. Blanco); (19) Angelita (Tulum); (20) Ka'an Lu'um (Tulum); (21) Zapote (also known as Hell's Bells, Benito Juárez); (22) Cocom (Solidaridad); (23) Crustacea (Solidaridad). 
A. cenotensis was also absent in locations from the municipalities of Temozon and Tinum (Figure 7). These cenotes have suffered drastic geomorphological modifications to a great extent and currently function as ecoparks that receive a high number of visitors (>200) regularly. There is evidence that common chemical compounds found in insect repellents and sunscreen used by tourists can exert negative effects on aquatic invertebrates. These include neurotoxicity, behavioral modifications, and decreased survival [101-108]. Therefore, tourism may negatively affect the species presence. Nevertheless, previous records exist from nearby locations, one of them corresponding to the species type locality (Gruta de Balamcanché) $[18,46,56]$. However, tourism in this location is restricted to the dry regions of the cave, which may have softened the negative environmental pressures that touristic swimming activities have over the environment.

\section{Conclusions}

A. cenotensis is a widespread species in the northern portion of the Yucatan Peninsula within the Quintana Roo and Yucatan states. The species exhibits conspicuously large populations and coexists with several endemic stygobiont representatives, some of which feed on it. Therefore, its protection would exert an umbrella effect over other stygobiont representatives inhabiting groundwater ecosystems, particularly those distributed within the cenote semicircle. Nevertheless, there is a lack of information regarding the species distribution in the hills and valleys, coastal and interior plains. Thus, more data on the species from these hydrogeological zones is required.

Its large populations and an apparent sensitivity to anthropogenic activities make $A$. cenotensis a potential key species that could function as a bioindicator. Thus, its incorporation into groundwater management, monitoring and protection programs, along with water quality data, would allow local authorities to assess the environmental health of groundwater ecosystems within the Yucatan Peninsula in a broader sense. Further bioassays and ecotoxicological studies on the effects of common contaminants used in anthropogenic activities over the species would be desirable in the future for further confirmation.

Finally, most of the current information on the species comes from taxonomic and distribution records. Hence, a better understanding of the biology and ecology of this widespread species would provide valuable information related to the processes and conditions that favor colonization and survival of stygofauna in groundwater habitats.

Supplementary Materials: The following are available online at https:/ / www.mdpi.com/article/10 .3390/d13040154/s1, Figure S1: PRISMA flow diagram 1, Figure S2: PRISMA flow diagram 2.

Author Contributions: Conceptualization, L.A.L.-B. and N.S.; methodology, L.A.L.-B.; software, L.A.L.-B.; validation, L.A.L.-B. and N.S.; formal analysis, L.A.L.-B.; investigation, L.A.L.-B.; resources, N.S.; data curation, L.A.L.-B.; writing—original draft preparation, L.A.L.-B.; writing-review and editing, N.S.; visualization, L.A.L.-B.; supervision, N.S.; project administration, N.S.; funding acquisition, N.S. All authors have read and agreed to the published version of the manuscript.

Funding: This research was partially funded by PAPIIT IN222716 “Biodiversidad y Ecología de la fauna de cenotes de Yucatán” and PAPIIT IN228319 “Hacia un mapa de biodiversidad acuática de cenotes de la península de Yucatán.

Institutional Review Board Statement: Not applicable.

Informed Consent Statement: Not applicable.

Data Availability Statement: The data presented in this study is available on request from the corresponding author. The resulting dataset from this work is publicly available in DarwinCore format and can be downloaded from Zenodo (https: / / doi.org/10.5281/zenodo.4391039).

Acknowledgments: L.A.L.-B. acknowledges the CONACYT scholarship (CVU/Becario: 864025/ 628560). Authors are grateful to Dorottya Angyal, Erick Sosa-Rodríguez (SDS), Ricardo MerlosRiestra, and Montserrat Revilla Hernández for their support in field work. We are grateful to Benjamín Magaña-Rodríguez for providing photographic material of A. cenotensis, Kayú VilchisZapata for providing photographic material related to the collection of specimens and field work. 
Authors are also grateful to the Secretaría de Desarrollo Sustentable del Gobierno de Yucatán (SDS) and L.A.L.-B. for providing transportation facilities during field work.

Conflicts of Interest: The authors declare no conflict of interest and the funders had no role in the design of the study; in the collection, analyses, or interpretation of data; in the writing of the manuscript, or in the decision to publish the results.

\section{References}

1. Mees, J.; Meland, K. World List of Lophogastrida, Stygiomysida and Mysida. Available online: http://www.marinespecies.org/ mysidacea (accessed on 24 November 2020).

2. Porter, M.L.; Meland, K.; Price, W. Global diversity of mysids (Crustacea-Mysida) in freshwater. Hydrobiologia 2008, 595, 213-218. [CrossRef]

3. Meland, K.; Mees, J.; Porter, M.; Wittmann, K.J. Taxonomic Review of the Orders Mysida and Stygiomysida (Crustacea, Peracarida). PLoS ONE 2015, 10, 1-28. [CrossRef] [PubMed]

4. Meland, K.; Willassen, E. The disunity of "Mysidacea" (Crustacea). Mol. Phylogenet. Evol. 2007, 44, 1083-1104. [CrossRef] [PubMed]

5. Rudstam, L.G.; Johansson, O.E. Advances in the ecology of freshwater mysids. Aquat. Biol. 2009, 5, 246-248. [CrossRef]

6. Coma, R.; Carola, M.; Riera, T.; Zabala, M. Horizontal transfer of matter by a cave-dwelling mysid. Mar. Ecol. 1997, 18, 211-226. [CrossRef]

7. Takahashi, K. Feeding ecology of mysids in freshwater and coastal marine habitats: A review. Bull. Plankt. Soc. Jpn. 2004, 51, 46-72.

8. Rastorgueff, P.A.; Harmelin-Vivien, M.; Richard, P.; Chevaldonné, P. Feeding strategies and resource partitioning mitigate the effects of oligotrophy for marine cave mysids. Mar. Ecol. Prog. Ser. 2011, 440, 163-176. [CrossRef]

9. Viherluoto, M.; Kuosa, H.; Flinkman, J.; Viitasalo, M. Food utilisation of pelagic mysids, Mysis mixta and M. relicta, during their growing season in the northern Baltic Sea. Mar. Biol. 2000, 136, 553-559. [CrossRef]

10. Punchihewa, N.N.; Krishnarajah, S.R. Trophic Position of Two Mysid Species (Crustacea: Mysidacea) in an Estuarine Ecosystem in Auckland, New Zealand, Using Stable Isotopic Analysis. Am. J. Mar. Sci. 2013, 1, 22-27. [CrossRef]

11. González-Ortegón, E.; Drake, P. Effects of freshwater inputs on the lower trophic levels of a temperate estuary: Physical, physiological or trophic forcing? Aquat. Sci. 2012, 74, 455-469. [CrossRef]

12. Mauchline, J. The Biology of Mysids and Euphausiids. In Advances in Marine Biology; Blaxter, J.H.S., Russel, F.S., Yonge, M., Eds.; Academic Press Inc.: Cambridge, MA, USA, 1980; Volume 18, p. 681, ISBN 0065-2881.

13. Roast, S.D.; Thompson, R.S.; Widdows, J.; Jones, M.B. Mysids and environmental monitoring: A case for their use in estuaries. Mar. Freshw. Res. 1998, 49, 827-832. [CrossRef]

14. Verslycke, T.A.; Fockedey, N.; McKenney, C.L.; Roast, S.D.; Jones, M.B.; Mees, J.; Janssen, C.R. Mysid crustaceans as potential test organisms for the evaluation of environmental endocrine disruption: A review. Environ. Toxicol. Chem. 2004, 23, 1219-1234. [CrossRef]

15. Anderson, B.; Phillips, B. Saltwater Toxicity Tests. In Marine Ecotoxicology; Elsevier: Amsterdam, The Netherlands, 2016; pp. 167-197.

16. Sket, B. The nature of biodiversity in hypogean waters and how it is endangered. Biodivers. Conserv. 1999. [CrossRef]

17. The National Speleological Society Survey and Cartography of The Underwater Caves of Quintana Roo Mexico. Available online: https:/ / caves.org/project/qrss/qrss.htm (accessed on 24 November 2020).

18. Creaser, E.P. Crustaceans from Yucatan. In The Cenotes of Yucatan. A Zoological and Hydrographic Survey; Pearse, A.S., Creaser, E.P., Hall, F.., Eds.; Carnegie Institution of Washington: Washington, DC, USA, 1936; pp. 117-132.

19. Reddell, J.R. A Preliminary Survey of the Caves of the Yucatan Peninsula; Reddell, J.R., Ed.; The Speleo Press: Austin, TX, USA, 1977; Volume 6.

20. Iliffe, T.M. An annotated list of the troglobitic anchialine and freshwater fauna of Quintana Roo. In Diversidad Biológica en la Reserva de la Biosfera de Sian Ka'an, Quintana Roo, México; Navarro, D., Suárez-morales, E., Eds.; CIQRO/SEDESOL: Quintana Roo, México, 1992; Volume 2, pp. 196-215, ISBN 9789686780055.

21. Pohlman, J.; Iliffe, T.; Cifuentes, L. A stable isotope study of organic cycling and the ecology of an anchialine cave ecosystem. Mar. Ecol. Prog. Ser. 1997, 155, 17-27. [CrossRef]

22. CONAGUA Programa Hídrico Regional 2014-2018 de la Región HidrológicoAdministrativa XII Península de Yucatán; CONAGUA: Ciudad de México, México, 2015; 140p.

23. Bauer-Gottwein, P.; Gondwe, B.R.N.; Charvet, G.; Marín, L.E.; Rebolledo-Vieyra, M.; Merediz-Alonso, G. Review: The Yucatán Peninsula karst aquifer, Mexico. Hydrogeol. J. 2011, 19, 507524. [CrossRef]

24. INEGI. Estudio Hidrológico del Estado de Yucatán; INEGI: Aguascalientes, Mexico, 2002; ISBN 9788578110796.

25. Schmitter-Soto, J.J.; Comín, F.A.; Escobar-Briones, E.; Herrera-Silveira, J.; Alcocer, J.; Suárez-Morales, E.; Elías-Gutiérrez, M.; Díaz-Arce, V.; Marín, L.E.; Steinich, B. Hydrogeochemical and biological characteristics of cenotes in the Yucatan Peninsula (SE Mexico). Hydrobiologia 2002, 467, 215-228. [CrossRef]

26. Liberati, A.; Altman, D.G.; Tetzlaff, J.; Mulrow, C.; Gotzsche, P.C.; Ioannidis, J.P.A.; Clarke, M.; Devereaux, P.J.; Kleijnen, J.; Moher, D. The PRISMA statement for reporting systematic reviews and meta-analyses of studies that evaluate healthcare interventions: Explanation and elaboration. BMJ 2009, 339, b2700. [CrossRef] 
27. NMNH Smithsonian National Museum of Natural History Invertebrate Zoology Collections. Available online: https: / / collections. nmnh.si.edu/search/iz/ (accessed on 5 February 2021).

28. UNAM. Colección Nacional de Crustáceos del Instituto de Biología, Universidad Nacional Autónoma de México. Available online: http:/ / www.ibiologia.unam.mx/colecciones/crustaceos/centro_crusta.htm (accessed on 5 February 2021).

29. Biodiversity Heritage Library. Available online: https://www.biodiversitylibrary.org/ (accessed on 5 February 2021).

30. HathiTrust Digital Library. Available online: https://www.hathitrust.org/ (accessed on 5 February 2021).

31. Scopus. Available online: https:/ / www.scopus.com/home.uri (accessed on 5 February 2021).

32. Web of Science Master Journal List-Search. Available online: https://mjl.clarivate.com/search-results (accessed on 5 February 2021).

33. Google Scholar. Available online: https://scholar.google.com/ (accessed on 5 February 2021).

34. Ocean Biodiversity Information System. Available online: https:/ / obis.org/ (accessed on 25 February 2021).

35. iNaturalist. Available online: https:/ / www.inaturalist.org/ (accessed on 5 February 2021).

36. GBIF. Available online: https:/ / www.gbif.org/ (accessed on 5 February 2021).

37. Bowman, T.E.; Mckenzie, H.; Murphy, S. A review of the genus Antromysis (Crustacea: Mysidacea), including new species from Jamaica and Oaxaca, Mexico, and a redescription and new records for A. cenotensis. In Studies on the Caves and Cave Fauna of the Yucatan Peninsula; Reddell, J.R., Ed.; The Speleo Press: Austin, TX, USA, 1977; Volume 6, pp. 27-38.

38. Chapman, A.D. Current Best Practices for Generalizing Sensitive Species Occurrence Data. Copenhagen GBIF Secr. 2020. [CrossRef]

39. CONABIO Geoportal del Sistema Nacional de Información sobre Biodiversidad. Available online: http://www.conabio.gob.mx/ informacion/gis/ (accessed on 20 February 2021).

40. Bitacora Ambiental del Programa de Ordenamiento Ecológico Territorial del Estado de Yucatán. Available online: https: / / bitacoraordenamiento.yucatan.gob.mx/index.php (accessed on 10 December 2020).

41. Angyal, D.; Chávez-Solís, E.M.; Liévano-Beltrán, L.A.; Magaña, B.; Simões, N.; Mascaró, M. New distribution records of subterranean crustaceans from cenotes in Yucatan (Mexico). Zookeys 2020, 911, 21-49. [CrossRef]

42. Bowman, T.E. Bahalana mayana, a new troglobitic cirolanid isopod from Cozumel Island and the Yucatan Peninsula, Mexico. Proc. Biol. Soc. Wash. 1987, 100, 659-663.

43. Yager, J. Speleonectes tulumensis, n. sp. (Crustacea, Remipedia) from two anchialine cenotes of the Yucatan Peninsula, Mexico. Stygologia 1987, 3, 160-166.

44. Holsinger, J. Tuluweckelia cernua, a new genus and species of stygobiont amphipod crustaceans (Hadzidae) from anchialine caves on the Yucatan peninsula in Mexico. Beaufortia 1990, 41, 97-107.

45. Ruiz-Cancino, G.; Mejía-Ortíz, L.M.; Lozano-Álvarez, E. Dinámica poblacional de Creaseriella anops (Crustace: Isopoda) en cenotes dulceacuícolas de Quintana Roo. In La Carcinologia el México; Researchgate: Berlin, Germany, 2013.

46. Fiers, F.; Reid, J.W.; Iliffe, T.M.; Suárez-Morales, E. New hypogean cyclopoid copepods (Crustacea) from the Yucatán Peninsula, Mexico. Contrib. Zool. 1996, 66, 65-102. [CrossRef]

47. Rocha, C.E.F.; Iuffe, T.M.; Reid, J.W.; Suarez-Morales, E.; Båmstedt, U. A new species of Halicyclops (Copepoda, Cyclopoida, Cyclopidae) from cenotes of the Yucatan Peninsula, Mexico, with an identification key for the species of the genus from the Caribbean region and adjacent areas. Sarsia 1998, 83, 387-399. [CrossRef]

48. Rocha, C.E.F.; Iliffe, T.M.; Reid, J.W.; Suárez-Morales, E. Prehendocyclops, a new genus of the subfamily Halicyclopinae (Copepoda, Cyclopoida, Cyclopidae) from cenotes of the Yucatan Peninsula, Mexico. Sarsia 2000, 85, 119-140. [CrossRef]

49. Pesce, G.L.; Iliffe, T.M. New records of cave-dwelling mysids from the Bahamas and Mexico with description of Palaumysis bahamensis n. sp. (Crustacea: Mysidacea). J. Nat. Hist. 2002, 36, 265-278. [CrossRef]

50. Strecker, U. The impact of invasive fish on an endemic Cyprinodon species flock (Teleostei) from Laguna Chichancanab, Yucatan, Mexico. Ecol. Freshw. Fish 2006, 15, 408-418. [CrossRef]

51. Boxshall, G.A.; Zylinski, S.; Jaume, D.; Iliffe, T.M.; Suárez-Morales, E. A new genus of speleophriid copepod (Copepoda: Misophrioida) from a cenote in the Yucatan, Mexico with a phylogenetic analysis at the species level. Zootaxa 2014, 3821, 321-336. [CrossRef] [PubMed]

52. Álvarez, F.; Iliffe, T.M.; Benítez, S.; Brankovits, D.; Villalobos, J.L. New records of anchialine fauna from the Yucatan Peninsula, Mexico. Check List 2015, 11, 1-10. [CrossRef]

53. Mejía-Ortíz, L.M.; Pipan, T.; Culver, D.C.; Sprouse, P. The blurred line between photic and aphotic environments: A large Mexican cave with almost no dark zone. Int. J. Speleol. 2018, 47, 69-80. [CrossRef]

54. Benítez, S.; Iliffe, T.M.; Quiroz-Martínez, B.; Alvarez, F. How is the anchialine fauna distributed within a cave? A study of the Ox Bel Ha System, Yucatan Peninsula, Mexico. Subterr. Biol. 2019, 31, 15-28. [CrossRef]

55. Sánchez, N.; Martínez, A. Dungeons and dragons: Two new species and records of Kinorhyncha from anchialine cenotes and marine lava tubes. Zool. Anz. 2019, 282, 161-175. [CrossRef]

56. Creaser, E.P. Larger Cave Crustacea of the Yucatan Peninsula. Carnegie Inst. Wash. Publ. 1938, 491, $159-164$.

57. Reddell, J.R. A Preliminary Bibliography of Mexican Cave Biology with a Checklist of Published Records. Assoc. Mex. Cave Stud. Bull. 1971, 3, 1-184.

58. Holthuis, L.B. Cave shrimps (Crustacea: Decapoda, Natantia) from Mexico. In Subterranean Fauna of Mexico; Accademia Nazionale dei Lincei Quaderno: Rome, Italy, 1977; pp. 173-195. 
59. Ariani, A.P.; Wittmann, K.J.; Franco, E. A Comparative Study of Static Bodies in Mysid Crustaceans: Evolutionary Implications of Crystallographic Characteristics. Biol. Bull. 1993, 185, 393-404. [CrossRef]

60. Barba-Macías, E.; Palacios-Vargas, J.G. Fauna acuática cavernícola de la Península de Yucatán. Mundos Subterráneos UMAE 1998, 9, 44-50.

61. Botosaneanu, L.; Iliffe, T.M. On four new stygobitic cirolanids (Isopoda: Cirolanidae) and several already described species from Mexico and the Bahamas. Bull. l'Institut R. Sci. Nat. Belg. Biol. 1999, 69, 111-141.

62. Chávez-Solís, E.M.; Mejía-Ortíz, L.M.; Simões, N. Predatory behavior of the cave shrimp Creaseria morleyi (Creaser, 1936) (Caridea: Palaemonidae), the blind hunter of the Yucatán cenotes, Mexico. J. Crustac. Biol. 2018, 38, 1-7. [CrossRef]

63. Angyal, D.; Solís, E.C.; Magaña, B.; Balázs, G.; Simoes, N. Mayaweckelia troglomorpha, a new subterranean amphipod species from Yucatán state, México (Amphipoda, Hadziidae). Zookeys 2018. [CrossRef]

64. Grego, J.; Angyal, D.; Beltrán, L.A.L. First record of subterranean freshwater gastropods (Mollusca, Gastropoda, Cochliopidae) from the cenotes of Yucatán state. Subterr. Biol. 2019, 29, 79-88. [CrossRef]

65. Pohlman, J.W.; Cifuentes, L.A.; Iliffe, T.M. Food Web Dynamics and Biogeochemistry of Anchialine Caves: A Stable Isotope Approach. In Ecosystems of the World; Wilkens, H., Culver, D., Humphreys, W., Eds.; Elsevier: Amsterdam, The Netherlands, 2000; Volume 30, pp. 351-363.

66. Schmitter-Soto, J.J. Catálogo de los Peces Continentales de Quintana Roo; El Colegio de la Frontera Sur: Chetumal, Mexico, 1996; ISBN 9687555041.

67. Medina-González, R.; Proudlove, G.; Chumba-Segura, L.; Iliffe, T. Threatened Fishes of the World: Ophisternon infernale (Hubbs, 1938) (Synbranchidae). Environ. Biol. Fishes 2001, 62, 170. [CrossRef]

68. Navarro-Mendoza, M. Inventario íctico y estudios ecológicos preliminares en los cuerpos de agua continentales en la reserva de la biósfera de Sian Ka'an y áreas circunvecinas en Quintana Roo, México; Centro de Investigaciones de Quintana Roo/Secretaría de Desarrollo Urbano y Ecología/United States Fish \& Wildlife Service: Washington, DC, USA, 1988.

69. Proudlove, G.; Medina-González, R.; Chumba-Segura, L.; Iliffe, T. Threatened Fishes of the World: Ogilbia pearsei (Hubbs, 1938) (Bythitidae). Environ. Biol. Fishes 2001, 62, 214. [CrossRef]

70. Sket, B. The ecology of anchihaline caves. Trends Ecol. Evol. 1996, 11, 221-225. [CrossRef]

71. Culver, D.C.; Pipan, T. The Biology of Caves and Other Subterranean Habitats; Oxford University Press: Oxford, UK, 2019; Volume 49, ISBN 9780198820765.

72. Calderón-Gutiérrez, F.; Sánchez-Ortiz, C.A.; Huato-Soberanis, L. Ecological patterns in anchialine caves. PLoS ONE 2018, 13, e0202909. [CrossRef]

73. Gibert, J.; Deharveng, L. Subterranean ecosystems: A truncated functional biodiversity. Bioscience 2002, 52, 473-481. [CrossRef]

74. Brankovits, D.; Pohlman, J.W.; Niemann, H.; Leigh, M.B.; Leewis, M.C.; Becker, K.W.; Iliffe, T.M.; Alvarez, F.; Lehmann, M.F.; Phillips, B. Methane-and dissolved organic carbon-fueled microbial loop supports a tropical subterranean estuary ecosystem. Nat. Commun. 2017, 8. [CrossRef] [PubMed]

75. Steinich, B. Investigaciones geofísicas e hidrogeológicas en el noroeste de la Península de Yucatán, México. Ph.D. Thesis, Instituto de Geofísica, Universidad Nacional Autónoma de México, México, 1996.

76. Alcocer, J.; Lugo, A.; Marín, L.E.; Escobar, E. Hydrochemistry of waters from five cenotes and evaluation of their suitability for drinking-water supplies, northeastern Yucatan, Mexico. Hydrogeol. J. 1998, 6, 293-301. [CrossRef]

77. Coke, J.G. Underwater Caves of the Yucatán Peninsula. In Encyclopedia of Caves; Elsevier: Amsterdam, The Netherlands, 2012; pp. 833-838, ISBN 9780123838322.

78. Iliffe, T.M.; Kornicker, L.S. Worldwide diving discoveries of living fossil animals from the depths of anchialine and marine caves. Smithson. Contrib. Mar. Sci. 2009, 38.

79. Gonzalez, B.C.; Iliffe, T.M.; Macalady, J.L.; Schaperdoth, I.; Kakuk, B. Microbial hotspots in anchialine blue holes: Initial discoveries from the Bahamas. Hydrobiologia 2011, 677, 149-156. [CrossRef]

80. Seymour, J.; Humphreys, W.; Mitchell, J. Stratification of the microbial community inhabiting an anchialine sinkhole. Aquat. Microb. Ecol. 2007, 50, 11-24. [CrossRef]

81. Van Beynen, P.; Townsend, K. A disturbance index for karst environments. Environ. Manag. 2005, 36, 101-116. [CrossRef]

82. Pacheco-Ávila, J.; Cabrera-Sansores, A.; Pérez-Ceballos, R. Diagnóstico de la calidad del agua subterránea en los sistemas municipales de abastecimiento en el Estado de Yucatán, México. Ingeniería 2004, 8, 165-179.

83. Aguilar-Duarte, Y.; Bautista, F.; Mendoza, M.E.; Frausto, O.; Ihl, T.; Delgado, C. Ivaky: Índice De La Vulnerabilidad Del Acuífero Kárstico Yucateco A La Contaminación. Rev. Mex. Ing. Química 2016, 15, 913-933.

84. Bautista, F.; Aguilar Duarte, Y.; Batllori, E. Amenazas, vulnerabilidad y riesgo de contaminación de las aguas subterráneas en la Península de Yucatán. Teoríay Prax. 2010, 7, 9-31. [CrossRef]

85. Casas-Beltrán, D.A.; Gallaher, C.M.; Hernandez Yac, E.; Febles Moreno, K.; Voglesonger, K.; Leal-Bautista, R.M.; Lenczewski, M. Seaweed Invasion! Temporal Changes in Beach Conditions Lead to Increasing Cenote Usage and Contamination in the Riviera Maya. Sustainability 2020, 12, 2474. [CrossRef]

86. Mateo-Sagasta, J.; Zadeh, S.M.; Turral, H. Water Pollution from Agriculture: A global Review; Food and Agriculture Organization of the United Nations (FAO): Rome, Italy; International Water Management Institute (IWMI): Colombo, Sri Lanka, 2017.

87. Lopez-Maldonado, Y.; Berkes, F. Restoring the environment, revitalizing the culture: Cenote conservation in Yucatan, Mexico. Ecol. Soc. 2017, 22, art7. [CrossRef] 
88. Hernández-Terrones, L.; Rebolledo-Vieyra, M.; Merino-Ibarra, M.; Soto, M.; Le-Cossec, A.; Monroy-Ríos, E. Groundwater Pollution in a Karstic Region (NE Yucatan): Baseline Nutrient Content and Flux to Coastal Ecosystems. Water Air Soil Pollut. 2010, 218, 517-528. [CrossRef]

89. INEGI. Anuario Estadístico y Geográfico de Yucatán 2014; INEGI: Mérida, Yucatán, Mexico, 2014; ISBN 9786077393658.

90. INEGI. Anuario Estadístico y Geográfico de Yucatán 2015; INEGI: Mérida, Yucatán, Mexico, 2015.

91. Lutz, W.; Prieto, L.; Anderson, W. Population, Development, and Environment on the Yucatán Peninsula: From Ancient Maya to 2030; ILASA: Laxenburg, Austria, 2000; ISBN 3-7045-0138-7.

92. Perez Brito, E.A.; de Jesus Espinosa Atoche, T.; Patricia Quintal Gordillo, K. Factors of Competitiveness for the Bovine Livestock in Yucatan, Mexico. In Bovine Science-A Key to Sustainable Development; IntechOpen: Rijeka, Croatia, 2019.

93. Danielopol, D.L.; Griebler, C.; Gunatilaka, A.; Notenboom, J. Present state and future prospects for groundwater ecosystems. Environ. Conserv. 2003, 30, 104-130. [CrossRef]

94. Arcega-Cabrera, F.; Garza-Pérez, R.; Noreña-Barroso, E.; Oceguera-Vargas, I. Impacts of Geochemical and Environmental Factors on Seasonal Variation of Heavy Metals in a Coastal Lagoon Yucatan, Mexico. Bull. Environ. Contam. Toxicol. 2015, 94, 58-65. [CrossRef]

95. White, W.B. Contaminant Transport in Karst Aquifers: Systematics and Mechanisms; White, W.B., Herman, J.S., Herman, E.K., Rutigliano, M., Eds.; Springer: Cham, Switzerland, 2018; pp. 55-81.

96. White, W.B. Hydrogeology of Karst Aquifers. In Encyclopedia of Caves; Elsevier: Amsterdam, The Netherlands, 2012; pp. 383-391, ISBN 9780123838322.

97. White, W.B. Karst Groundwater Contamination and Public Health; White, W.B., Herman, J.S., Herman, E.K., Rutigliano, M., Eds.; Advances in Karst Science; Springer International Publishing: Cham, Switzerland, 2018; Volume 13, ISBN 978-3-319-51069-9.

98. Kløve, B.; Ala-Aho, P.; Bertrand, G.; Gurdak, J.J.; Kupfersberger, H.; Kværner, J.; Muotka, T.; Mykrä, H.; Preda, E.; Rossi, P.; et al. Climate change impacts on groundwater and dependent ecosystems. J. Hydrol. 2014, 518, 250-266. [CrossRef]

99. Arcega-Cabrera, F.; Velázquez-Tavera, N.; Fargher, L.; Derrien, M.; Noreña-Barroso, E. Fecal sterols, seasonal variability, and probable sources along the ring of cenotes, Yucatan, Mexico. J. Contam. Hydrol. 2014, 168, 41-49. [CrossRef] [PubMed]

100. Kantun Manzano, C.; Arcega-Cabrera, F.; Derrien, M.; Noreña-Barroso, E.; Herrera-Silveira, J. Submerged Groundwater Discharges as Source of Fecal Material in Protected Karstic Coastal Areas. Geofluids 2018, 2018, 1-11. [CrossRef]

101. Boyd, A.; Stewart, C.B.; Philibert, D.A.; How, Z.T.; El-Din, M.G.; Tierney, K.B.; Blewett, T.A. A burning issue: The effect of organic ultraviolet filter exposure on the behaviour and physiology of Daphnia magna. Sci. Total Environ. 2021, 750, 1-11. [CrossRef]

102. Gao, L.; Yuan, T.; Zhou, C.; Cheng, P.; Bai, Q.; Ao, J.; Wang, W.; Zhang, H. Effects of four commonly used UV filters on the growth, cell viability and oxidative stress responses of the Tetrahymena thermophila. Chemosphere 2013, 93, 2507-2513. [CrossRef] [PubMed]

103. Olmstead, A.W.; LeBlanc, G.A. Toxicity Assessment of Environmentally Relevant Pollutant Mixtures Using a Heuristic Model. Integr. Environ. Assess. Manag. 2005, 1, 114-122. [CrossRef] [PubMed]

104. Ruszkiewicz, J.A.; Pinkas, A.; Ferrer, B.; Peres, T.V.; Tsatsakis, A.; Aschner, M. Neurotoxic effect of active ingredients in sunscreen products, a contemporary review. Toxicol. Rep. 2017, 4, 245-259. [CrossRef] [PubMed]

105. Seo, J.; Lee, Y.G.; Kim, S.D.; Cha, C.J.; Ahn, J.H.; Hur, H.G. Biodegradation of the insecticide N,N-diethyl-m-toluamide by fungi: Identification and toxicity of metabolites. Arch. Environ. Contam. Toxicol. 2005. [CrossRef] [PubMed]

106. Aronson, R.B.; Swanson, D.W. Video surveys of coral reefs: Uni- and multivariate applications. In Proceedings of the 8th International Coral Reef Symposium; Lessios, H.A., Macintyre, I.G., Eds.; Smithsonian Tropical Research Institute: Panama City, Panama, 1997; Volume 2, pp. 1441-1446.

107. Giokas, D.L.; Salvador, A.; Chisvert, A. UV filters: From sunscreens to human body and the environment. TrAC Trends Anal. Chem. 2007, 26, 360-374. [CrossRef]

108. Brausch, J.M.; Rand, G.M. A review of personal care products in the aquatic environment: Environmental concentrations and toxicity. Chemosphere 2011, 82, 1518-1532. [CrossRef] [PubMed] 